\title{
TÜRK HUKUKUNDA KANUN HÜKMÜNDE KARARNAME UYGULAMASI VE SORUNLAR
}

\author{
Prof. Dr. Turgut TAN*
}

\section{GIRIS}

Bilindiǧi gibi Kanun Hükmünde Karamame (KHK) müessesesi hukukumuza 1961 Anayasası'nda (m. 64), 1971 yılında yapılan değişiklikler sırasında girmiştir. 12 Eylül 1980 askeri müdahalesinden sonra Milli Güvenlik Konseyi tarafından çıanlan bir kararla ${ }^{1} 1961$ Anayasası'nın KHK'lerle ilgili maddesinde bazı değişiklikler yapılmışur.

1982 Anayasası ise hukuki rejimleri farklı iki KHK türü kabul etmiştir. Olağaniustü hal ve sıkıyönetim sırasında çıkartılan KHK'ler ilk kez ozel bir hukuki rejime bağlanarak düzenlenirken; olağan dőnemde çıkanlacak KHK'ler de 1961 Anayasasinndan farklı biçimde düzenlenmişıir. Iki Anayasa arasındaki farklılıklar şoyle ozetlenebilir.

1982 Anayasası'na göre yetki yasasında yürürlükten kaldırılacak yasa hükümlerinin gősterilmesine gerek yoktur. Buna karşlık yetki süresi içinde birden çok KHK çıkarılıp çıkarılamayacağının yetki yasasında gösterilmesi gerekmektedir. Gene 1982 Anayasası'ndaki düzenlemeye göre, Bakanlar Kurulunun istifası, dủşürülmesi veya yasama döneminin bitmesinin, belli süre için verilmiş olan yetkinin sona ermesine neden olmıyacağı hükmü getirildiği gibi: KHK'nin süre bitiminden once TBMM tarafından onaylanması sırasında, yetkinin son bulduğu veya süre bitimine kadar devam ettiğinin belirtilmesi de ơngörülmüş̧ür. verilemez.

1982 Anayasası'na (m. 163) göre, KHK ile bütçede değişiklik yapma yetkisi

1971 Anayasa değişikliği ilc hukukumuza giren KHK müessesinin giderek yaygın bir uygulama alanına kavuşup, yasanın yerini alan bir olağan düzenlemeye düş̧üğu dikkat

\footnotetext{
*A.O. Siyasal Bilgiler Fakültesi, Oğretim Oyesi

${ }^{1}$ MGK'nin 64 sayılı Kararı. RG. 12.1.1982, sayı: 15572 (mükerrer).
} 
çekmektedir. Bu yaygın uygulama ileride üzerinde duracağımız pek çok hukuki sorunu da beraberinde getirmiştir.

1971-1993 yıllan arasında 17 adet yetki yasası çıkanıldıł̆ı gorülmektedir. Aynca, bazı yetki yasalannda deģişiklik yapan beş adet yasa çikarılmışur. tleride aynnulı olarak ele alacağımız gibi, yetki yasalarının bazı aynk durumlar dışında genelde kamu kurum ve kuruluşlarının yeniden düzenlenmesi, idari usullerde düzenlemeler yapılması, memurlar ve diğer kamu gơrevlilerine ilişkin yasalarda de ģş̧iklik yapılmasına ilişkin oldukları görülmekterir.

Yetki yasalarnna dayanılarak 12.2.1976-8.9.1993 tarihleri arasında çıanlan KHK sayısı ise 426 'dır. Numara verildiği halde çıkarılamamıs $98 \mathrm{KHK}$ olduğu için son yayınlanan KHK'nin numarası (524)'tür. Çıkarilan bu 426 KHK'den yasalaşanlann sayısı 114 olup, 4 tanesi reddedilmiş, 75 tanesi yürürlükten kaldırılmış, 12 tanesi Anayasa Mahkemesince iptal edilmiş olup, 238 tanesi de halen TBMM'nde görüşmeyi beklemektedir.

$\mathrm{Bu}$ incelememizde ơnce olağan dőnemde çıkarılan KHK'lere ilişkin bazı hukuki sorunları ele aldıktan sonra, clağanüstü hal ve sıkıyönetim sırasında çıkarılan KHK'lere değineceğiz.

\section{ANAYASAL ÇERÇEVE VE KHK UYGULAMALARI}

Anayasa (m. 91) bakanlar kuruluna KHK çıkrma yetkisi veren yasayı içerik ve usul açısından ozel olarak düzenlemiş; yetki yasasının bağli olduğu koşullar da Anayasa Mahkemesi kararlarıyla somutlaştırılıp açıklığa kavuşırulmuştur. Bu açıdan, bakanlar kuruluna KHK çıkarma yetkisi verme yoluna ancak ivedi ve zorunlu durumlarda gidilmeli; yetki belli konularda verilmeli; Anayasa'nın KHK'lerle düzenlenmesini yasakladığı alanlara girilememelidir. Üzerinde durulması gereken bir başka nokta da yetki yasasının özel bír yasal düzenlemé niteliğini gözardı eden uygulamalardır.

\section{A. YETKİ YASASII VE ANAYASAL GEREKLER} Gerekir.

1. KHK Çıkarma Yoluna İvedi ve Zorunlu Durumlarda Gidilmesi

KHK müessesesini hukumuza sokan anayasal düzenlemelerin gerekçesinde, yasama usulünün ağırlığı nedeniyle ivediliği gerektiren durumlarda hızla gereken düzenlemeleri yapabilmek için, bu yolun kabul edildiği belirtilmektedir. Dolayısıyla, Anayasa Mahkememiz de yetki yasalannın denetimini yaparken bu gereğe uyulup uyulmadığını araşurmaktadır.

Yukarıda da değinđiğirniz gbi, genelde yetki yasalannın konusunu oluşturan, kamu personeline ve idari usule ilișikin düzcnlemelerin bu nitclikte olup olmadıkları Anayasa Mahkemesi tarafından tartı̧ıılmışır. Yüksek Mahkemeye göre "Niteliği itibariyle uzun süreli ve çok yönlü çalışmaları zorunlu kılan personel mevzuatı génelde ivediliği gerektiren bir konu olarak değerlendirilemez. Tam aksine personel mevzuatunın, kısa süreli ve ivedi kararnameler yerine, bir plana dayalı uzun süreli çalışmalarla, sık sık 
değişmeyecek kurallarla düzenlenmesinin gereklililı̆i ileri sürülebilir. ${ }^{\text {2 }}$. Gerçekten, bu konuda verilen yetkilerin süresi toplandıł̆ında beş yıla yakın oldư̛̆u gorrilmektedir ki, bu durum Anayasa Mahkemesine göre "Bir yasama dönemine yaklaşı bir süre içerisinde yetki alınan konulardaki düzenlemelerin bitirilmemiş olması da işin ivedi ve hemen yerine getirilecek türden olmadığın göstermektedir." ${ }^{3}$. Dikkat ceken bir baska yơn de, bu alanda çıkarilan 40'dan fazla KHK'den biri bile TBMM"nde gơrüşülmeden verilen yetkinin beş yil içinde üç keż uzaulmış olmasıdır.

Benzer durum idari usul konusunda da görülmektedir. Anayasa Mahkemesine gore, "Bakanlar Kuruluna idari usul ve işlemlerin yeniden düzenlenmesi için çok kasa bir kesinti dikkate alınmadığında alu yıldan fazla bir yelki verilmiştir. Bu süre TBMM'nin bir yasama doneminden fazladır. Yasanın diğer oğeleri Anayasa'ya aykunlık oluşurmasa bile Bakanlar Kuruluna bu kadar uzun süre için yetki verilmesi, yasama yetkisinin devri niteliǧindedir." ${ }^{\text {. }}$.

\section{KHK Çıkarma Yetkisi Belli Konularda Verilmelidir.}

1982 Anayasası (m. 91) KHK ile ilgili düzenlemesinde 1961 Anayasasinda (m. 64) olduğu gibi, KHK çıkarma yetkisinin belli konularda verileceğini soylememekle beraber, TBMM'nin yetkilerini düzenlerken ( $\mathrm{m}$. 87) "Bakanlar Kuruluna belli konularda kanun hükmünde karamame çıkarma yetkisi vermek" deyimini kullanmaktadir.

Nitekim Anayasa Mahkemesine göre de "91. madde bu sözcüklerin bulunmamass, yasama organının Bakanlar Kuruluna herhangi bir boyutta bir yetki devrine olanak vermez. Cü̉nkü, 87. madde Bakanlar Kuruluna verilecek KHK çikarma yetkisinin ancak belli konularda olabileceğini çok açık gőstermektedir. Bu durumda TBMM Bakanlar Kuruluna, ancak belli konularda bu yetkiyi verebilir, her konuyu kapsyacak genigjlikte bir KHK çıkarma yetkisi veremez." 5 .

Bakanlar Kuruluna verilen yetkinin konusunun yeki yasasında mutlak belirgin biçimde gösterilmesi gerektił̧ini vurgulayan Anayasa Mahkemesine göre, KHK'nin "amacı ve kapsamı da konusu gibi geniş içerikli her yöne çekilebilecek yuvarlak ve genel anlaumla gösterilmemeli, değişik şekillerde yorumlamaya elverişli olmamalıdır"6.

\section{KHK Çıkarma Yetkisi Anayasa'nın Yasaklamadığı Konularda Verilmelidir.}

Anayasa (m. 91) sıkıyönetim ve olağanüstü haller saklı kalmak uzere, "Anayasanın ikinci kısmının birinci ve ikinci bolümlerinde yer alan temel haklar, kişi haklar ve odevleri ile dördüncü bölümde yer alan siyasi haklar ve odevler " KHK lerle düzenlenemez. Yeuki yasalarının Bakanlar Kuruluna KHK ile düzenleme yapma yetkisi

\footnotetext{
2 Anayasa Mahkemesinin 1.2.1990 tarih ve E.988/64-K.990/2 sayıl karari. RG; 21.4.1990, sayı: 20499. s. 18.

3 Ibid, s. 24.

${ }^{4}$ Anayasa Mahkemesinin 6.2 .1990 tarih ve E. $988 / 62-$ K. $990 / 3$ sayılı karan, RG: 12.10 .1990 , say1: 20663 , s. 25 .

5 Anayasa Mahkemesinin 990/2 sayılı kararı RG: 21.4 .1990 sayı: 20499, s. 15.

${ }^{6}$ Anayasa Mahkemesinin $990 / 3$ sayılı karari RG: 12.10 .1990 , sayı: 20663, s. 16.
} 
verdiği bazı konulann, doğrudan olmasa da dolaylı biçimde Anayasa'nın yasakladığı alana girdiği ileri sürülebilmektedir.

Örneģin, 3268 sayılı Yasanın (m.2/d) idari, mali ve sosyal haklannda günün ekonomik koşullarına uygun ilarak yeni düzenleme ve değişiklikler yapılacak kamu gorrevlileri arasında 2802 sayılı Yasaya bağlı yargı̣ ve savcılann da bulunması konusunda Anayasa Mahkemesi,

"Mahkemelerin bağımsızlı̆̆ı ile hakimlik ve savcılık teminatı açısından getirilen esaslarla hakim ve savcılara tanınan hakların neler oldugu Anayasa'nın 138., 139. ve 140. maddelerinde duraksamaya yer bırakmayacak bir açıklıkla belirtilmiştir. Bunlann, Anayasa'nın ikinci kısmının birinci, ikinci ve dördüncü bollümlerinde yer alan ve KHK'lerie düzenlenemiyecę̆i Anayasa'nın 91. maddesinde açıklanan haklarla hiçbir ilgisi bulunmamaktadır" dedikıen sonra, "dolaylı biçimde kişi hak ve özgürlükklerini ilg,ilendirmeyecek bir düzenleme düşünmek oldukça güçtür. Bu nedenle de dolaylı bir ilginin varlığına dayanılarak sonuca gitmek isabetli sayılama:.."

sonucuna varmaktadır?

Yargıtay'a ait mali hakların yasa yerine KHK'lerle (241 ve 243) düzenlenmesini "bir yanılgı" olarak niteleyenler ${ }^{8}$ olduğu gibi, memur hukukunun özü ve kaynağını "kamu hizmetlerine girme hakkı"nın oluşturduğunu ve bunun da KHK'lerin düzenleme alanı dışında kalan "siyasi haklar ve ödevler" bölümünde yer aldığına dikkat çekenler de vardir 9 .

Bazen de KHK'nin Anayasada KHK ile düzenlenemiyecegi belirtilen konulan düzenleme konusu yaptı̆̆ı, ancak bu hükümlerin yürürlüğünü KHK'nin yasalaşması tarihine bırakı̆̆ı gözlenmektedir. Bu şekilde Anayasa'ya uygunluk denetiminden kurtulmak mümkün müdür? Anayasa Mahkemesi KHK'nin tüm maddclcrinin, yürürlükte olsun olmasın Anayasa'ya uygunluk denetimine tabi tutulması gerektiğini belinterek, "KHK'nin bir maddesinin yuirürlügünün belli bir tarihe bırakılması ile yasalaşma koşuluna bağlanması arasında anayasal denetim açısından ayrım yoktur. Yürürlügüü yasalaşma koşuluna bağlanan madde anayasal denetime bağlı tutulamıyacaksa, belli bir tarihte yürürlüğge girmesi öngörülen maddenin de Anayasa'ya uygunluk denetiminin yapılması gerekir. Oysa, belli bir tarihte yürürlüğe girecek maddenin anayasal denetiminin yapılması zorunludur. Çünkü, aksi halde soyut norm denetiminden kaçırılmış olur." demektedir ${ }^{10}$.

${ }^{7}$ Anayasa Mahkamesinin 6.1.1987 tarih ve E. 986/15 - K. 987/1 sayıh kararı. RG: 4.10.1987, sayı: 19594, s. 13-14.

${ }^{8}$ M. Çemberci, Kanun Hükmünde Kararnameler, Cumhuriyet Gazetesi, 28.1.1986, s. 2.

${ }^{9}$ L. Duran, Kanun Hükmünde Karamame, AID. c. 8, sayı: 2, s. 4 vd.; F. Sağlam, Kanun Hukmünde Karamame Çıkarma Yetkisinin Sınırları, Uygulamanın Yaygınlaştırılmasından Doğabilecek Sorunlar, Anayasa Yargisı, Ankara, 1984, s. 268 vd.; E. Özbudun, 1961 ve 1982 Anayasalarında Kanun Hükmünde Karamameler, Anayasa Yargısi, Ankara, 1987, s. 231 vd.

${ }^{10}$ Anayasa Mahkemesinin 4.4.1991 tarih ve E. 990/12 - K. $991 / 7$ sayılı karari. RG: 13.8.1991, sayı: 20959, s. 50-51 


\section{B. YETKI YASASININ ÖZELLIGI}

Yasa koyucunun bazı đurumlarda bir yetki yasası çıkarmak yerine normal bir yasa ile yürürlükte bulunan bir yetki yasasına gönderme yaparak KHK çıkarma olanağı yarattığı gozlenmektedir. Ömeł̆in, mahalli idareler seçimine ilişkin 2972 sayılı Yasa (Geçici m. 5) "Bu kanunda seçim usul ve esasları hükme bağlanan büyük sehir yönetiminin hukuki statüsü, bu kanunun yürürlüğünü takip eden ilk seçimin oy verme gününden önce, 16.6.1982 gün ve 2680 sayılı Kamu Kurum ve Kuruluşlarının Kuruluş Görev ve Yetkilerinin Düzenlenmesi ile ilgili yetki Kanununda belirilen esas ve usullere uygun olarak çıkarılacak kanun hükmünde kararnamelerle düzenlenir" hükmünü getirmiştir. 2972 sayılı Yasaya karşı açılan iptal davasında bu hükmün de, 2680 sayılı Yetki Yasasının yalnızca merkezi idareyi ilgilendirip mahalli idareleri kapsamadiğı, dolayısıyla maddenin yeni bir yetki yasası niteliği taşıdığı; oysa yetki yasasında bulunması gereken oğelerin bulunmadığı gerekçeleriyle Anayasa'ya aykın olduğu ileri sürülmüş̧ür.

Anayasa Mahkemesi'ne göre,

"Bir tedvin yöntemi olan atıfla Kanun Koyucu, daha once yürürlüge koydư̆u bir hükmü, ilgisi nedeniyle bașka bir konudaki düzenlemeye alabilir. Boyle olunca aufta bulunulan hưküm, yeni kanun tarafindan da benimsenmiş, bünyesine girmiş demektir. Bu itibarla bir kanunda yazılı olan bir hükümle, yürürlükte olan diğer bir kanunda yer almış olan hükme veya hükümlcre yapilan auf arasında bir aynm yapılamaz."

Dolayısıyla, Yüksek Mahkemeye gore, 2972 sayll Yasa Bakanlar Kuruluna yeuki verirken 2680 sayılı Yetki Yasasındaki amacı, kapsamı, ilkeleri ve yetki süresini yinelemek yerine $o$ unsurları aynen benimsemiş olmaktadır ${ }^{11}$.

Bir yasanın daha ónce çıkanımıs bir yetki yasasına atıf yaparak Yetki Yasası koşulunun yerine getirildið̌ini kabul etmek olanaksızdir ${ }^{12}$. Herşeyden once, 2680 sayılı Yetki Yasası ayn kamu tüzel kişileri olan yercl idarelere ilişkin ilkeler içermemektedir. Nitekim, Anayasa Mahkemesi büyük sehir belediyelerinin ve belediyelerin yapılanna, organlarına ilişkin bazı düzenlcmeler yapan 355 sayılı KHK ile ilgili kararında bu KHK'nin dayanağı olan 3347 sayılı Yeuki Yasasının, "kamu kurum ve kuruluşlan"nı kapsadığı, bunların içinde yerel yönetimlerin kabul edilemiyeceğ $i$, yerel yőnetimlerin idarenin bütünlüğü içinde ozerk yapısı ve ozzellikleriyle ayrı bir alan olduklan gerekçesiyle, 355 sayılı KHK'nin yetki yasası ile verilmeyen bir yetkinin kullanılması sonucu dayanaksız ve geçersiz duruma düştưgùine karar vermiştir ${ }^{13}$.

11 1.3.1984 tarih ve E.984/1-K.984/2 Karar. RG: 1.5.1984, sayı: 18388, s. 7 vd.

12 Karşıy yazan sayın Y.G. Ozden'e göre. "2680 No.lu yetki yasası, ilgili olmayan bir yasa ile 2972 nolu yasa ile de değiştirilip genişletilemeýeceği gibi bu yasa bir yetki yasası sayılamaz. Yetki yasasının anayasal niteliklerini taşımamakıadı" RG: 1.5.1984. sayı: 18388 , s. 61 .

138.2.1989 tarih ve E.988/38-K.989/7; RG: 3.5.1989, sayı: 20157 s. 48 vd. 
Anayasa Mahkemesirin 2972 sayılı Yasaya ilişkin kararında benimsediği yaklaşımın ortaya yanıtlanması zor pek çok sorun çıkardığ 14 bir gerçektir. Nitekim bu sorunlar Yüksek Mahkemenin 3479 sayılı Yasa ile ilgili kararında yeniden tartışma konusu olmuştur. Anayasa Mahkemesi, bir yandan 3268 ve 3347 sayılı yetki yasalannda değişiklik yapıp sürelerini uzatırken bir yandan da 2954 sayılı TRT Yasasında değişiklik yapan 3479 sayılı Yasayı, yaptığı göndermeler nedeniyle "yetki yasası" niteliğinde kabul edip Anayasa'ya aykın olmadığını soylerken, "once yasaya atıf yapmak yerine, Anayasa'nın 91. maddesindeki amaç, kapsam, ilke gibi unsurların tekrarlanması daha isabetli ise de böyle yapılmayıp atıf yoluyla eski yasanın süresinin uzatılması ya da yeni eklemeler yapılması ile yetinilmesi... bir tedvin yőntemidir. Daha sonraki yasa ile yürürlükte olan bir yetki yasasında yeralan amaç, kapsam, ilke gibi unsurları tekrarlmakla, onceki yasa hükmüne auf arasında onemli bir fark bulunmamaktadır." 15 demektedir.

Yüksek Mahkemeye g̊öre, 3479 sayılı Yasa'nın 2954 sayılı Yasa'da dę̆işiklik yapan 3. maddesi yönünden durum farklıdır.

"3479 sayılı Yasa'nın 3. maddesiyle bu genel düzenleyici yasada değişiklik yapılmıştır. 3479 sayılı Yasa'nın 3. maddesi Anayasa'nın 91. maddesindeki unsurlan içeren ve bu maddeye göre oncelikle ve ivedilikle görüşülüp kabul edilen bir yeıki yasası hükmü değildir. Yasa koyucunun yeni bir yasa irkararak başka bir yasada değişiklik yapmasının usul yönünden Anayasa'ya aykırı bir yönü bulunmamakıadı" 16 .

Yüksek Mahkeme bu son karanı ile benzer tutumu sürdürmekle birlikte, altunı çizdǐ̆imiz deyimlerden de anlaşılacă̆ı gibi, bu yorumda biraz zorlandığı izlenimini de vermektedir. Kaldı ki, bu son kararı ile Anayasa Mahkememiz, içinde normal yasa kurallan yanında yetki yasası niteliğinde kurallar da içeren karma yapılı atipik yasa türünü de ortaya çıkarmaktaclır. Bu durumda, içeriği ve görüşülme usulleri bakımından farklı đüzenlenmiş olan kurallar aynı yasa içinde yer aldıklarında, o yasanın hangi hukuki rejime tabi olacağı sorusu açıkta kalmaktadır. Yüksek Mahkemenin bu tutumunu bütçe yasalan ile ilgili olarak yukarıda ömeklerini verdiğimiz ve istikrar kazanmış olan içtihadı ile bağdaşırma olanağını da bulamamaktayız. Kanımızca bu uygulama yetkisinin saptırılmasından başka bir şey.değildir.

\section{KHK'LERİN DÜZENLENMESINE VE TBMM'NDE GÖRÜŞÜLMESINE ILİ̧KIN SORUNLAR}

\section{A. KHK'LERIN KAPSAMINA ILIŞKIN BAZI GÖZLEMLER}

Ülkemizdeki KHK uygulaması incelendiğinde sakıncalı bazı uygulamalar gozlenmektedir. Bunların båşında aynı KHK içinde birbiri ile iliş̧isi olmayan farklı konuların düzenlenmesi gelmektedir. Bir başka sorun da, bir konuyu düzenleyen KHK henüz TBMM'nde görüşülmełien aynı konuyu düzenleyen başka KHK'lerin çıkarılmasıdır. Nihayet üçüncü bir grup sorun da yașama tekniğine ilişsin olanlardır.

${ }^{14} \mathrm{Tan}$, Kanun Hükmünde Karamame Uygulaması. AlD, c. 17, sayı 4, s. 37 vd.

151.2 .1990 tarih ve E.988/64-K.990/2;RG: 21.4 .1990 , sayı 20499 , s. 10.

${ }^{16}$ lbid, s. 18. Y. Aliefendioğlı̀nun karşıyu için bkz. s. 31. 


\section{Birbiri ile tlişkisi Olmyan Konuların Aynı KHK tçinde Düzenlenmesi}

Düzeltilmesi gereken bir uygulama birbiri ile ilişkisi olmayan konulann aynı KHK içinde düzenlenmesidir. Bu tür uygulamalann tipik'bir ơmegi 1211 sayılı T.C. Merkez Bankası Kanunu ile 2547 sayılı Yüksekőgretim Kanununda da de ğişiklik yapan 422 sayılı Kadının Statüsü ve Sorunlan Başkanlığını kuran KHK ${ }^{17}$ 'dir. Ote yandan, bu tür uygulamaların yaygınlaşması karşısında KHK'lerin başlıklanında konulanın gostermek de bazen olanaksız hale geldiģi için "çeşitli Kanun ve Kanun Hükmünde Karamamelende Deł̧işiklik Yapılması Hakkında Kanun Hükmünde Kararname ${ }^{n 18}$ şeklinde başlıklara sıkça rastlanır olmuştur.

Bu tür uygulamalann yanlışlığı geç de olsa farkedilmiş olacak ki, 1991 yılında çıkarılan 3755 sayılı Yetki Yasasında (m. 3/f) "Bu yetki kanunun uygulamasinda biri diğerinden ilişkisiz konular aynı kanun hükmünde karamame metninde yer alamaz" hükmüne yer verilmiştir.

\section{Aynı Konuda Birbirini Izleyen KHK'ler Çıkarılması}

Uygulamada aynı konuda ve bazen kısa aralıklarla birbirini izleyen çok sayıda KHK çıkanıldığı olmaktadır. Bilindiğ̆i gibi, Anayasa'ya (m. 91) göre KHK'ler resmi Gazetede yayınlandıkları gün TBMM'ne sunulmak zorundadur. Bu durumda KHK henüz TBMM tarafından ele alınıp görüşülmeden aynı konuda baskka KHK'ler yürürluğe girmektedir. Dolayısıyla, TBMM bir konuda KHK ile yapılan dizenleme konusunda iradesini ontaya koymadan aynı konuda yeni bir KHK çıkanlmıs olmaktadır.

Böyle durumlarda TBMM'nde bulunan pratik çőzüm, aynı konuyu düzenleyen KHK'lerin birleştirilerek göruşülmesi olmaktadır. Ancak, TBMM'nin KHK üzerindeki yetkisi aynen kabul, değiştirerek kabul veya red şeklinde ortaya çıkacağından ve deģiştirerek kabulde de değişikliklerin Resmi Gazetede yayınlanma ile yürürrüğe gireceģi kabul edildiğinden, bu şekilde birbiri ardına deģişiklik geçirmiş KHK'lerin TBMMne kabulünde bazı sorunlar ortaya çıkmakıadır ${ }^{19}$.

\section{Yasama Tekniğine Illişkin Sorunlar}

KHK uygulamasında bazen yasama tekniği açısından ilginç ơrneklere de rastlanmaktadır. Örneğin TEK'in ozelleştirilmesi amacıyla çıkanlan ve 3291 sayılı Yasanın özelleştirmeye ilişkin hükümlerinde de değişiklikler yapan 513 sayılı KHK ${ }^{20}$, bazı maddelerindc (ek $\mathrm{m}$. I ve $\mathrm{m}$. 4) "3291 sayılı kanun hükümlerine göre yapılır" veya "3291 sayılı kanunun bu KHK'ye aykırı olmayan hükümleri uygulanır" gibi deyimler kullanmaktadır. Bu tür düzenlemeer 513 sayılı KHK'nin 3291 sayılı Yasanın hükümlerini

\footnotetext{
${ }^{17}$ RG: 20.4.1990, sayı: 20498 (muikerrer)

18 Orneğin 351 sayılı KHK RG: 30.12.1988, sayı: 20035 (mükerrer)

${ }^{19} \mathrm{Tan}$. loc. cit. AlD, c. 17 , say1: 4 , s. 44.

20 RG. 13.9.1993, say1: 21697 .
} 
değiştirmemesine karşın, 3291 sayılı Yasadan bağımsız düzenleme olduğu izlenimini vermektedir.

Bu düzenleme biçinininin, TEK'in ozelleştirilmesi için, aynen PTT"nin (T)'sini ozelleştirmek için Türk telekomünikasyon AŞ. kurulmasına ilişkin 509 sayılı KHK benzeri bir KHK çıkarmak üzere düzenleme yapıldıktan sonra bundan vazgeçilip 3291 sayılı Yasanın değişiklik yolına gidilmek istenmesinden kaynaklandığı izlenimi edinilmektedir.

\section{B. KHK'LERIN TBMM'NDE GÖRÜSUULÜP ONAYLANMASINA ILISKIN SORUNLAR}

\section{KHK'lerin "Öncelikle" ve "Ivedilikle" Görüşülmesi}

Anayasa'ya (m. 91) göre KHK'leri Resmi Gazetede yayınlandıklan gün TBMM'ne sunulmakta, komisyonlar ve Genel Kurulda öncelikle ve ivedilikle görỉşülmektedir. Ancak, uygulamaya bakuğımızda bu anyasal gereğe uyulmadığı gözlenmektedir. Zira, bugüne kadar çıkanlmış 400'ü aşkın KHK'den yarısı halen komisyonlarda beklemektedir.

Bilindiği gibi, "öncelik" bir yasa tasarısının gündemin "Kanun Tasan ve Teklifleri ile Komisyonlardan gelen işler" kısmının başına konulması anlamına gelmektedir. Ivedilik ise bir tasannın 48 saat bekleme süresini dolduran Genel Kurulda görüşülmesidir. Içtüzüğe göre "ivedilik" istemi Hükümet veya Esas Komisyon tarafından yapılabilmektedir (lç tüzül: m. 53). Hatta, bir yetki yasasının ivedilikle gơrüşülmesi yolunda bir siyasal parti grup baskanvekili tarafından yapılan onerinin kabul edilmesinin Anayasa'ya aykırılı̆̆ı savını değerlendiren Anayasa Mahkemesi, Içtüzükte ivedilik onerisinin Hükümet veya : siyasal parti grup başkanvelkili tarafından yapılan öneri üzerine alınan ivedilik karannın Anayasa'da (m. 91) yetki yasasının ivedilikle görüşülme gereł̆inin yerine getirilmesini sağladığı için Anayasa'ya aykırı olmadığına karar vermiştir ${ }^{21}$. TBMM Anayasa hükmü gereği KHK'lerin gơrü̧̧ülmesinde oncelik ve ivedilik koşuluna uymak zorundadır.

Bir başka sorun TBMM'ne sunulan KHK'lerin hangi suraya göre görüşüleceł̆idir. Bu konuda bir usul kuralı tulunmadığı için uygulamada daha ónce çıkarılmış bir KHK dururken sonraki KHK'lerin ele alınıp görüşüldü̈̆ü olmaktadır. Nitekim, 2-10 sayılı KHK'ler dururken 11 sayılı KHK'nin ele alınıp görüşülmesinin Anayasa'ya aykın olduğu ileri sürülmüş, Anayasa Măhkemesi ise KHK'lerin "gündemdeki öteki Kanun tasan ve tekliflerinden öncelik ve ivedilikle görüşülüp karara bağlanması"nın Anayasa gereği olduğunu, bunun sağlanmıasının yeterli olduğunu belirterek Anayasa'ya aykırılık görmemiştir 22 .

TBMM'ne sunulan KHK'lerin yıllarca görüşülmek üzere bekletilmesi ve aradan uzun süre geçtikten sonra TBMM tarafından KHK'nin değiştirilmesi veya reddi yoluna gidilmesinin hukuk düzeninde güven açısından bazı sakıncalar taşıdığı bir gerçektir. Bu nedenle yakın tarihlerde yapılmış çeşitli anayasalar da bazı çözümler getirilmeye

21 12.12.1991, E. 991/27-K. 991/50 sayılı karar, AMKD, sayı: 27, c. 2. s. 679 vd.

2214.10 .1975 tarih E. 975/1.45-K.975/198 sayılı karar. AMKD; sayı : 17, s. 565-567. 
çalışılmışur ${ }^{23}$. Bu arada KHK'ne sunulduğu gün komisyona gönderilmesini, komisyonda belli slire içinde sonuçlandırılmaması halinde TBMM Başkalığında doğrudan Genel Kurula indirileceğine ilişkin içtüzük düzenlemesi onerileri de vardır²4.

\section{TBMM'nin KHK'yi Kabul veya Red Kararları}

TBMM, Anayasa'ya (m: 91) gore bir KHK'yi reddedebilir veya kabul edebilir. Kabul de aynen veya değiştirerek kabul biçimlerinde ortaya çıłabilir. TBMM'nin bu iradesi bir yasa seklinde ortaya çıkmaktadır. Ancak, uygulamaya bakuǧgumızda bu tür işlemlerin değiş̧ik biçimlende yapıldığı da gözlenmektedir.

Ömeğin, TBMM bir yasa ile daha başka KHK'lerle deģiştirilmiş veya kaldınlmıs KHK'leri yürürlükten kaldırmaktadır. Kullanılan formül sayılan KHK'lerin "tüma ile" yürürlükten kaldırılmış olduğudur. Bu tür yasalarda (őmeğin 3641, 3714, 3743 ve 3776 sayılı yasalar) 42 adet KHK yürürlükten kaldırılmışur. TBMM'nin KHK'ler tizerindeki yetkisi red, aynen veya değiştirilerek kabul ile sınırlandırıldığına göre bu tür yürürlükten kaldırma biçimindeki işlemlerin durumu taruşılabilir.

Öte yandan, TBMM'nin bazen KHK'nin "bütün sonuçlan ile beraber red ve iptal" edildiğine ilişkin yasa çıkanıldı̆̆ı da görülmektedir. Öneğin 11 sayılı KHK'ye ilişkin 1896 sayılı Yasa. Oysa, Anayasa'ya göre TBMM KHK'yi reddedebilir ve KHK red karannın Resmi Gazetede yayınlandığı tarihte yürürlükten kalkar. Dolayısıyla, KHK'nin geriye yürür sonuçlarla ortadan kaldırılması Anayasa'ya uygun bulmak mümkün değildir ${ }^{25}$.

Bir başka ilginç uygulama ise 5590 sayılı Ticaret ve Sanayi Odalan, Ticaret Odalan, Sanayi Odalan, Deniz Ticaret Odalan ve Ticaret Borsaları Birliģ̨i Kanununun değiştirilmesi hakkında 63 ve 82 sayılı KHK'lerin deģiştirilerek kabulä aşamasında yaşanmışır. Sơz konusu KHK'lerin değiş̧tirilerek kabulüne ilişkin yasa tasansı komisyonlardan geçerek Genel Kurula gelmiş ve tümü üzerindeki gőrißşmelerden sonra maddelere geçilmesi kabul edilmemiştir. Bu karann nasıl formüle edileceği konusunda yaşanan duraksamadan sonra 63 ve 82 sayılı KHK'lerin deģiştirilerek kabulü hakkında "Kanun Tasarısının maddelerine geçilmesinin reddi aynı birleşimde kararlasurulmıs ve soz konusu Kanun Hükmünde Kararnameler yürürlükten kaldınımışur" başığını taşıyan "TBMM Kararı" olarak Resmi Gazetede yayınlanmıșur ${ }^{26}$. Bu yőntemin doğruluğu da tartışılabilir. Zira, bu örnekte Komisyonun olumlu raporu benimsenmedił̧i için Komisyona geri verme yolun gidilebileceği (lç tüzük m. 81) gibi, gőrüşmeler sonunda reddi bir yasa ile karara bağlanabilirdi.

Nihayet, ozellikle yasama tekniği açısından, ilginç gördügüümuz bir uygulamadan örnek vermek isteriz. Bakanlar Kurulunun bazı yasalann Bakanlar Kuruluna yetki veren hükümlerinde değişiklik yapmak üzere çıkardığı KHK'nin TBMM tarafından deģiştirilerek kabulüne ilişkin yasa "7.2.1990 tarih ve 3612 sayılı Bazı Kanunların Bakanlar Kuruluna Yetki Veren Hükümlerinde Deģişiklik Yapılması Hakkında Kanun Tasansı ile Bazı

${ }^{23}$ Bkz. 1976 Portekiz An. m. 168; 1975 Yunanistan An. m. 44. 1978 Ispanya An. m. 86.

${ }^{24}$ Tan, loc. cit, AlD, c. 17, sayı 4, s. 41 vd.

25 Onbilgin ve Oytam. op. cit., s. 127-128; Yilmaz, op. cit., s. 548.

2617.10 .1984 tarih ve 9 sayılı TBMM Karan. RG. 3.1.1985, sayı: 18624, s. 1. 
Kanunların Bakanlar Kuruluna Yııtki veren Hükümlerinde: Değişiklik Yapılması Hakkında Kanun Hükmünde Kararnamesin Değiştirilerek kabılü Hakkında Kanun"27 adını taşımaktadır. Oysa bir yasa tasarısının kabul edildił̌i gibi alışılmamış ve üstelik hukuki açıdan pek de isabetli olmayan bir başlık kullanmak yerine, KHK'nin değiştirilerek kabulüne iliş̧kin yasada, sơz: konusu yasa tasansında yer alan farklı düzenlemeler varsa onlara da yer verilebilirdi.

\section{KHK'LERIN YAßGISAL DENETIMI}

\section{A. YARGISAL DENETIMIN KAPSAMI}

\section{Yetki Yasasına Uygunluk Açısından}

Anayasa'ya (m. 146) gơre Anayasa Mahkemesi... kanun hükmünde karamamelerin... Anayasa'ya şeki: ve esas bakımlarından uygunluğunu denetler". Anayasa Mahkemesine göre de,

"KHK'nin yargısal denetiminin sơz konusu oldư̆unda KHK'nin kendisinin hera yeixi yasasına hem de Ana yasa'ya uygunluğu sorunlannn çoziumlenmesi gerclir. Hemekadar, Anayassinnn 148. maddesinde KHK'lerin yetki yasalariıa uy'gunluğunun denetlenmesinden sőz edilmekte ise de, Anayasa'ya uygusluk denetiminin içerisine óncelikle KHK'nin yetki yasasına uygunlựunun denetimi girer. Çünkü, Anayasa'da, Bakanlar Kuruluna ancak yc:lki yasasında belirtilen sınırlar içerisinde KHK çlcarma yetkisi verilmiştir. Yetki yasası olmazsa (Anayasa md. 121 dışında) KHK olmaz... Boylece, $3 . \mathrm{HK}$ 'nin yetki yasasına aykun olması Anayasa'ya aykın olması ile ozdışleșir." 28 .

Anayasa Mahkemesirıe giı'e KHK yasa gücünü, dayandığı yetki yasası ile konulan esaslara uygunluğu ve yeıki viasasının da anayasa'ya uygunluğu varsayıldığı için kazanmaktadır. Dolayısıyla, yetk i yasasının Anayasa'ya aykınlığı nedeniyle iptaline karar verilmesi halinde, bu yetki y:ısası a dayanılarak çıkarılan KHK'ler de anayasal dayanaktan yoksun hale geleceklerdir. Bu né'enlerle "Bir yetki yasasına dayanmadan çkartulan veya dayandığı yetki yasası Anayasa'yı aykırı olan bir KHK'nin kurallan, içerikleri yơnünden Anayasa'ya aykırılık oluşturrnasal ar bile, Anayasa'ya uygunluğundan sớz edilemez ${ }^{29}$.

Sonuç olarak, dayanıdığı yetki yasası iptal edilmiş olan KHK, Anayasa'nın Başlangıç'ında yer alan egernenli ̧̧i "Millet adına kullannaya yetkili bulunan hiçbir kişi ve kuruluşun, bu Anayasa'da "'రosterilen hürriyetçi demokrasi ve bunun icaplanyla belirlenmiş hukuk düzeni dışına çıkamayacağı", 2. małddesindeki "hukuk devleti"; 6. maddedeki "Hiç bir kimse visya organ kaynağını Anayası'dan almayan bir devlet yetkisi kullanamaz" ilkeleriyle, 91. rnaddıssine aykırılık oluşturaciăgndan iptal gerekmektedir. Bu

${ }^{27}$ RG: 16.2 .1990 , say1: 20435 .

285.2.1992 tarih E. 990/22-E.992/6 sayılı karar RG. 27.11.1993, sayı: 21773, s. 55 vd.

2921.10.1993 tarih ve E. 993ß.9-K.993/40-2 sayılı karar: RG. 6.11.1993, sayı: 21750 . s. 31 . 
gerekçe ile Anayasa Mhkemesi'nce daha once iptal edilmiş olan 3911 sayılı. Yetki Yasasına dayanan KHK'ler de iptal edilmiştir. ${ }^{30}$

\section{KHK'nin Içeriğini Denetlemek Gerekir mi?}

Dayandığı yetki yasası iptal edilen KHK'nin içeriğinin Anayasa'ya uygunluğu tartş̧ılmadan iptalinin gerekeceği yönündeki bu tutum taruş̧labilir. Kaldı ki, Anayasa Mahkemesi kararlarında ${ }^{31}$ "Yetki yasasının iptalinin, buna dayanılarak çkarılan KHK'lerin etkisi konusunda tek veya kesin bir esas koymaya ve bu dogrnuluda yorum yapmaya olanak yoktur. Olayın Anayasa Mahkemesi onüne getiriliş biçimi.. yani iptal davası ya da itiraz yolu ile aykırılık savında bulunulmuş olması değisịik sonuçlar ortaya çıkarabilir. Aynca, KHK'nin dayandığı yetki yasașının iptali gerekçesi, iptali istenen KHK'nin anayasal durumunu belirleyecektir". Dolayısıyla, yetki yasasının iptalinin buna dayanan KHK'lerin otomatik iptalini gerektireceği tarışılmalıdır.

Yetki yasasının Anayasa Mahkemesi'nce iptalinin başka bir gerekçe aranmadan ona dayanılarak çıkarılmış KHK'lerin de iptalini gerektireceği yơnündeki Anayasa Mahkemesi kararlarına karşıoy yazan üyelerin gerekşeleri şరyle ozetlenebilir.

"Yürütme tarafından yasal düzenleme yetkisinin KHK olarak kullanılması, yürütmenin diğer yetkilerinin kullanılmasından farklı değildir. Yetkinin, kullanıldığı gün yasal temeller ve sınırlar içinde kullanılmıs olması yeterlidir. Yetkinin kullanılmasından sonra yetkili organın yetkisinin kaldınlması o organın daha once yaptı̆ı işlemleri yetki yönünden kusurlu hale getirmez. Ortada yetki yasasina dayanilarak ve yasal usullere göre konulmuş bir KHK vardur. Surf daha sonra kalkan bir yetki nedeniyle KHK'nin Anayasa'ya aykın sayılması yürütmeye verilen yetkinin doğasına ve devletin devamlılı̆̆ı anlayışına aykundır." 32

${ }^{30}$ KHK/503 konusunda 6.10.1993, E.993/34-K.993/33 sayıl1, RG; 4.12.1993, say1: 21778 , s. 5 vd.

KHK/508 konusunda 6.10.1993, E. 993/40-K.993/38 sayılı, RG; 3.12 .1993 , sayı: 21777 , s. 19 vd.

KHK/511 konusunda 25.11.1993, E. 993/50-K.993/52 sayılı, RG; 27.12.1993, say1: 21801 , s. $15 \mathrm{vd}$.

KHK/512 konusunda 25.11.1993, E. 993/46-K.993/48 sayıl1, RG; 23.12.1993, sayı. 21797 , s. 49 vd.

KHK/513 konusunda 25.11.1993, E. 993/44-k.993/45 sayılı, RG; 21.12.1993, sayı: 21795 , s. 51 vd.

KHK/514 konusunda 6.10.1993, E. 993/41-K.993-39 sayılı, RG; 8.12.1993, sayı: 21782, s. 17 vd.

KHK/515 konusunda 25.11.1993, E. 993/43-K.993/46 sayıl1, RG; 14.12.1993, sayı: 21788 , s. 21 vd.

KHK/516 konusunda 25.11.1993, E. 993/47-K.993/49 sayıl, RG; 24.12.1993, sayı: 21798 , s. 25 vd.

31 17.7.1990 tarih ve E. 990/1-K.990/21 sayılı ve 4.4.1991 tarih ve E. 990/12-K.991/7 sayilı karar.

${ }^{32}$ G. Dinçer'in 993/32 sayılı karara karş10yu, RG: 10.11.1993, sayı: 21754, 8. 54-55. 
"KHK lukuk alemine çıkuğı tarihte yetki yasası var mıdır yok mudur buna b:akılrrialıdır. Yetki yasası, KHK'ye bu hayatiyeti verdikten sonra onun yürürlükten kalkmasi, süresinin sona ermesi KHK'nin yasal dayanaktan yolssun kaldığı anlamına gelmez. ${ }^{33}$

"Iptal edilen yetki yasasına dayanan bazı KHK'ler (omeǧin 503, 508 , $514,520,524)$ salı yetki yasasının iptali nedeniyle iptal edilirken Anayasa Mahkemesince; alti aylik bir süre tanınaraik bu KHK'lere bir süre yaşam hakkı tanınmasi bit biriyle çelişmektedir". ${ }^{34}$

Anayasa Mahkemesi'nin 3911 sayılı Yetki Yasasının iptali uzerine ona dayanan KHK'leri başka bir gerekçe arıınadan iptal yoluna gitmesi ónceki bazı kararlarında

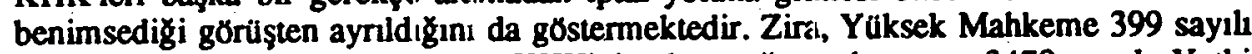
KHK'ye karşı açılan davada tıI KHK'nin dayanağını oluşıran 3479 sayılı Yeuki Yasasının iptal edilmiş olması neteniyle 399. sayılı KHK'nin de iptali gerektiği savını değerlendirirken;

"Yetki yasasının iptal edilmesi durumunda buna dyanılarak çıkanlan KHK' 'erin hukuki durumlan onemli bir sórun olușturmaktadır. Bu konuda kesin bir yorurn yafmaya olanak yoktur. Aykırllk savının iptal ya da itiraz yoluyla getirilmiş olması ve yetki yasasının iptal gerekçesi KHK'nin Anayasa karşısındał:i konumunu etkileyecek tir.

demektedir ${ }^{35}$. Anayasa Mahl:emosine göre,

"Öncelikle belirtmek gerekir ki 399 saylı KHK 3479 sayılı Yetki Yasası'nın kapsamı içinde olup, bu yasa iptıl edilmeden once çıkarılmışur. Anayasa'nın 1.53. maaddesinde Anayasa Matkemesi iptal kararlarının geriye yürümeyeceği öngè rülmüștür. Bu nedenle çıkarldıklan tarihte yürürlükte olan bir yetki yas śsına dayanan KHK'lerin daha sonra bu yetki yasası Anayasa'ya aykin bulunarak iptal edilse biles salt bu nedenle iptaline olanak görülmemektedir. ${ }^{36}$

Bununla beraber Anayasa Mahkemesi bu kararında yekki yasasının Anayasa'nun 91. maddesinde sayılan oğelerdın bisine aykın olması nedeniyle iptali durumunda ise buna dayanan KHK'lerin iptalinin gerkleceğini belirtmekte; ancak Anayasa Mahkemesi'nce ilk kez yetki yasasının denetiminde uygulanan bir yorumla getirilen "önemli ivedi ve zorunlu olma" olçütlerinin Anayasa Mahlıemesi kararının Resmi Ciazetede yayınlanmasından ónce çıkarılan KHK'lere uygularımasıı ın ve bu KHK'lerin anılan olçütlere göre Anayasa'ya aykırılık nedeniyle iptali "istil:sarsızlık, kararsızlık ve güvensizlik yaratacă̌ı" gibi Anayasa Mahkemesi karariarının geçmişe yürümeyeç:ği yolundaki kurala da aykın olacağ 1 sonucuna varmaktadir ${ }^{37}$.

${ }^{33}$ H. Kılı̨ ve S. Adalinın karşıoyı, ibid; s. 57.

${ }^{34} \mathrm{G}$. Dinçer' in karş10yu, ibid; s. 55 .

35 4.4.1991 E.990/12-K.991/, AMKD; sayı: 27, c. 1, s. 2.15 .

36 lbid.

37Ibid., s. 217. 


\section{3. "Yürürlüğün Durdurulması" Uygulaması}

Anayasa Mahkemesi PTT'nin (T)'sinin ozelleştirilmesi olarak bilinen 509 sayılı Türk Telekomünikasyon Anonim Şirketi Kurulması Hakkında Kanun Hükmunde Kararnameye karşı açılan iptal davasında ilk kez yürürlự̆in durdurulması karan vermiştir $^{38}$. Oysa, Yüksek Mahkeme daha onceki kararlannda ${ }^{39}$ yasalarm uygulanmassnı durdurma yetkisi olmadığına hükmetmişti. Buna karşılık oğretide 40 Anayasa Mahkemesinin yürütmeyi durdurma yetkisinin bulundư̆u ve kullanılması gerektiği savunuluyordu.

Anayasa Mahkemesi'nin 509 sayılı KHK'ye karşı açılan iptal davasında yürürlưguin durdurulması karan verilirken şu gerekģeleri ileri sürmuşstür.

- Yargısal denetimin etkinliğinin ozünde varolan bir araçur.

- Kamu yarannı kollayıp ileride giderilmesi güļ̧ ve olanaksız durumlann ortaya çımasını engellemek için gereklidir; zorunluluktur,

- Yasalarda açıķ̧a bulunmasa bile "onlem" yetkisinin varsayılması bir

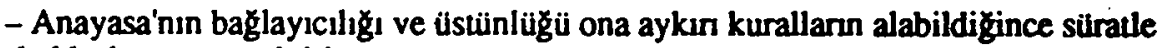
ortadan kaldırılmasını gerektirir,

- Uygulanmakla hükmünü yerine getiren yasalar (ölüm cezalarının yerine getirilmesi, devletleştirme vb.) için bir tür "koruma ónlemi" olarak dụşünullmelidir.

- Iptal yetkisi tanınınca daha hafif sonuçlan olan yürürlügüü durdurulması evleviyetle tanınmıs sayılır,

- Yasalarda açıkça yer almasa da yargıcın hukuk yaratma yetkisi çą̆das hukuk sistemlerinde benimsenmektedir. 44 sayılı yasa gereğince de Anayaa'nun ustuinlưguna sağlayacak gerekli usul kurallannı uygulamayı Anayasa Mahkemesi görevinin doğal sonucu saymaktadir.

- Anayasa Mahkemesi yetki tanıyan kurala değil, yetkiyi yasaklayan kuralın bulunup bulunmadiğına bakar.

Anayasa Mahkemesi'nin ilk kez verdiği bu yürürlự̆ durdurma karan oğretide "evrensel üstún hukuk ilke ve kuralları ile pekiştirilmiş olan TC Anayasası'nın, kişikerin

3821.10.1993, E.993/33-K.993/40-2; RG. 6.11.1993, sayi: 21750, s. 21-27.

396.4.1972, E.972/13-K.972/18, AMKD, sayı: 10, 24.5.1977. E. 977/60-K.977/81, AMKD; sayı: 15 s. 358 vd.

40N. Bilge, Iptal Kararlarının Geriye Yürümezliģi, Cumhuriyet Gazetesi, 19.4.1990; K. Yenice, Anayasa Mahkemesi Kararlerma Etkinlik, Cumhuriyet Gazetesi 3.11.1986; Y. Okçuoğlu, Kanunların Uygulanmasını Durdurma Yetkisi, Cumhuriyet Gezetesi, 17.11.1984, s. 2. 
hak arama ve savunma haklanı ile adil ve güvenli yargılanması gereł̧ini ve mahkemelerin bağımsızlığı ile kararlarının yerine getirilmesini sał̆lama zorunluluğunu ongőren ve emreden düzenlemelerinden kaynaklanan yargıcın genel onlem alma yetkisini çok doğru ve tam yerinde" kullanılması olarik nitelenmiştir ${ }^{41}$.

\section{OLAGANÜSTÜ HAL KHK'LERI}

\section{A. OLAĞ}

Olą̧anüstü yơnetim usulleri 1982 Anayasasunda ayrunulı biçimde düzenlenmiştir. Buna göre olał̧anústü yơnetim usulleri ų̣̈ durumda sőz konusu olmaktadır: "Tabii afet ve ăğr ekonomik bunalım sebebiyle olaģanüstü hal ilanı" (m. 119); "şiddet olaylannın yaygınlaşması ve kamu düzeninin ciddi şekilde bozulması sebepleriyle olaģanüsti hal ilanı" (m. 120) ve nihayet "sıkıyőnetim, seferberlik ve savaş" (m. 122). Bu üç durum Cumhurbaşkanının başkanlığında toplanan Bakanlar Kurulunca yurdun bir veya birden fazla bolgesinde veya bütünündo altı ayı aşmamak üzere ilan edilmektedir. Bakanlar kurulu "tabii afet ve ekonomik bunalım nedeniyle" ilan edilen olağanüstü hal dışında bu kararı vermeden Milli Güvenlik Kurulu'nun görüşünü almak zorundadır. Karar Resmi Gazetede yayınlanmakta ve heinen TBMM'nin onayına sunulmaktadır. Tatilde ise

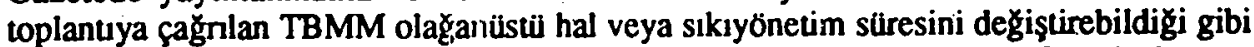
kaldırabilmektedir. Aynı şekilde Bakanlar Kurulunun onerisi üzerine her defasında dơrt ayı geçmemek ïzere uzatabilmektedir.

Sıkıyönetim ile olağanüstii hal arasındaki farklılık sıkı yonetim ilanı ile beraber kolluk görev ve yetkilerinin askeri makamlara geçmesine karşın, olağanüstii hallerde sivil makamların yetkilerinde genişleme olmaktadır. Bir başka farklılı da sıkıyơnetimde bazı suçların askeri mahkemelerde yargılanmasına karşın, olał̧anüstü halde yargı gorevi adli yarginindir.

\section{Olağanüstü Hallerdeki KHK'ler ${ }^{42}$}

Anayasa (m. 91) genel olarak KHK çıkarma yetkisini düzenlerken, sıkıyönetim ve olałanủstỉ hallerde Cumhurbaşkanının başkanlığında toplanan Bakanlar Kunulunun KHK çıkarmasına ilişkin hükümleri saklı tutmakta, olağanüstü hal ve sıkıyőnetimi düzenlerken, "olağanüstü hal süresince" veya "sıkıyönetim süresince" Cumhurbaşkaninın başkanlığında toplanan Bakanlar Kurulunun "olağanüstü halin gerékli kıldığı konularda" ve "sıkıyőnetim halinin erekli kıldığı konularda" KHK'ler çıkarılabileceł̧i ongörülmektedir (m. 121/3 ve 122/2). Gene bu hükümlere göre çıkarılacak KHK'ler Resmi Gazetede yalınlandıkları gün TBMM'nin onayına sunulacaklardır. KHK'lerin TBMM'nde onaylanmasına ilişkin süre ve usul içtüzükte belirlenecektir. Hemen belirtelim ki, 1982 Anayasası'ndan sonra TBMM Içtïzügü henüz yapılmadığından bu kararnamelerin TBMM'nce onaylanmasına ilişkin usul belirsizdir. Bu nedenle TBMM'nin onama yetkisini kullanamayacağını savunanlar vardı43. Bugüne kadar uygulama olağan

${ }^{41}$ L. Duran, Yasama Işleminin Askıya Alınması, Cumhuriyet Gazetesi, 7.11.1993.

${ }^{42}$ Y. Aliefendioğlu, Anayasa Yargısı Açısından Olağanüstú Yönetim Usulleri, 'AlD; c. 25. sayı: 2 , 1992. s. 25 vd.; M. Turhan, Olağanüstü Hallerde Çıkanılabilecek Kanun Hukmunde Karamameler, AID c. 25 , sayı: 3, s. 1992 , s. 13 vd.

43 Aliefendioğlu, loc. cit; s. 37-38. 
KHK'ler gibi görüşülüp yasa haline getirilme yơnünde olmuştur (Ömeğin 2935 sayılı Olą̧anüstü Hal Kanununda değişiklik yapan 201 sayılı KHK olağan KHK'ler gibi gơrüşülüp 3076 sayılı Yasa haline donüş̧üşşür). Olạ̛anüstu hal KHK'lerinin diǧerlerinden önemli farkı yetki yasasına gerek olmadan çıkanlabilmeleridir.

Olağanüstü haller ve sıkıyönetim sırasında çıkanlacak KHK'lerin içerik açısından da olağan KHK'lerden farkı vardır. Zira, Anayasa (m. 91) olažan dönemlerdekj KHK'lerle "Anayasanın ikinci kısmının birinci ve ikinci bolümlerinde yer alan temel haklar, kişi haklan ve oddevleri ile dordüncü bollümde yer alan siyasi haklar ve odevler"in düzenlenemiyeceğini ơngörürken, sıkıyonetim ve olağanüstü hallerin saklı olduğunu belirtmek suretiyle bu konuların sukıyonetim ve olağanüstü hallerde çıkanlacak KHK'lerle düzenlenmesine izin vermektedir. Bir baska deyimle, sıkıőnetim ve olağanüstü hallerde çıkarlacak KHK'lerle "temel hak ve ózgürlükler sınırlandırılabilecek hatta durdurulbilecektir"44.

Esasen 1982 Anayasasi'nda (m. 15) "Savaş, seferberlik, sıkıyơnetim veya olağanüstü hallerde, milletlerarası yükümlülükler ihlal edilmemek kaydıyla, durumun gerektirdiği ólçüde temel hak ve hürriyètlerin kullanılması kısmen veya tamamen durdurulabilir veya bunlar için Anayasa'da ongorülen güvencelere aykın tedbirler alınabilir" hükmü yer almaktadır. Anayasa'ya göre bu hükmün de "Birinci fıkrada belirtilen durumlarda da, savaş, savaş hukukuna uygun fiiller sonucu meydana gelen olümler ile, olüm cezalarının infazı dışında, kişinin yaşama hakkına, maddi ve manevi varlığının bütünlü̧̆üne dokunulamaz; suç ve cezalar geçmişe yürütúlemez; suçlulư̆u mahkeme kararı ile saptanıncaya kadar kimse suçlu sayılamaz" denilmektedir.

Dolayısıyla, milletlerarası hukuktan doğan yükümlülüklerin ihlal edilmemesi kaydı, ollçülülük ilkesi ve "çekirdek alana dokunmama" yasağı getirilerek Anayasa Mahkemesine "haylı etkin bir anayasaya uygunluk denetimi olanağ" verdiği ve bu açidan 1982 Anayasasının 1961 Anayasasından daha üstün gơründügü savunulmakıadir. ${ }^{45}$.

\section{Olaganüstü Hal Yasası ve KHK'ler}

Anayasadaki düzenlemeleri yinelemekle yetinen 2935 sayılı Olağanüstü Hal Kanununa (m. 4) göre, "Olağanüstü hal süresince, Cumhurbaşkanının başkanlığında toplanan Bakanlar Kurulu, olaģanüstü halin gerekli kıldığı konularda Anayasanın 91 nci maddesindeki kısıtlamalara ve usule bağlı olmaksızın, kanun hükmünde karamameler çıarılabilir. Bu kararnameler Resmi Gazetede yalımlanır ve aynı gün Türkiye Büyülk Millet Meclisinin onayına sunulur." Maddenin bu haliyle bazı sorunlar yaratması tehlikesi olduğundan Tasarının Danışma Meclisindeki görüş̧mesi sırasında de ̧̧işiklik onergeleri benimsenerek farklı bir metin kabul edilmiş̧ił ${ }^{46}$. Zira, Tasarının Danışma

${ }^{44}$ Turhan, loc. cit., s. 19.

45 Ibid, s. 21 .

${ }^{46} \mathrm{~T}$. Tan'in maddenin "Olağanưstú hal süresince Cumhurbaşkanının başkanlığunda toplanan Bakanlar Kurulu olağanústú hal ilanım gerektiren nedenlerin ortadan kaldırilması. durumun gerektirdiği konularda kanun hükmünde karamameler çkarabilir.

"Bu kararnameler Resmi Gazetede yayınlanır ve ayn gun Turkiye Buyulk Millet Meclisinin onayına sunulur. 
Meclisi Genel Kurulundaki görüşmesinde çıkanlacak KHK'lerin, olağanüstü hal ilanını gerektiren nedenler dikkate alınar ak onların ortadan kaldınılmasına yơnelik olacaklan ve olayla sınırh olduklan konusunda görüş birliğji dikkat çekmektedir.

2935 sayılı Yasanın ( $m_{.}$4) KHK'lerle ilgili bu genel düzenlemesi dışında, ağır ekonomik bunalım (m. 7) ve fara yükümlülü̆gü $(m .9)$ konularında da KHK'lerle dizenleme yapılabileceği on "ekonominin düzenlenmesi ve iyileștirilmesi amact ile mal, sermaye, hizmet piyasalannı yonlendirici, vergi, para, kredi, kira, ucret ve fiyat politikalarını belirleyici ve çalışmaya iliskkin her türlü tedbir ve yükümliilüklerin tesbiti konulannda Bakanlar Kurulunca kanun hükmünde karamame çıkanlabilir. ${ }^{\text {" }}$

Bu düzenleme, olağanül:tü hal sırasında çıkarılacak KHK'lerin konusunu belirginleştirme olarak yorumlan ıbileceği gibi; Bakanlar Kurulunun Cumhurbaşkanının başkanlığında toplanmasına gerek olmadan. KHK çıkarabileceği biçiminde de yorumlanabilir.

Olağanüstü hal uygulaması sırasında çıkanlan KHK'lerde gơddưgüumüz bir aksaklık ilk uygulamada kendini gősterrniştir. Zira, 201 sayılı "2935 sayılı Olağanüstủ Hal Kanununun'11. maddesine üç bend ile Kanuna bir Ek Madde Eklenmesi Hakkında" KHK, adından da anlaşılacă̆ı gibi, 2!35 sayılı Yasada de ̧̌işiklik yapmaktadır. Böyle bir düzenlemenin olağanüstü hal uygulanan bőlgenin dışına tał̧an bir kapsamı olduğu açıktır.

Aslında, 2935 sayılı Yasada değişiklik yapan 201 sayılı KHK yerine iki yol izlenebilirdi: Birincisi, 2935 sayıı Y Ysanın değış̧irilmesi hakkında bir yasa çıkarmak-ki doğru olanı da budur-; ikincisi, Anayasa'nın 121. ve 2935 :ayılı Yasanın 4. maddesindeki yetki kullanılarak çıkanlacak bir KHK ile, 2935 sayılı Yasayı deģ iştirmek yoluna gitmeden, olağanüstü hal ilan e:ilen bolgede 201 sayılı KHK'nin getirdiği tedbirleri alabilme yetkisini tanımak. Zirra bu tür yetkilerin tanınmasi için bunların ơnce 2935 sayll Yasada öngorrülmesine gerek yoktur.

Anayasa Mahkemesinin de, denetimi dışında kalan KHK'leri belirlerken uyguladığı konu, yer, zaman ölçütleri de bunı doğrulamaktadır.

\section{B. OLAĞaNÜSTÜ HAL KHK'LERININ DENETIMI}

Olağanüstü hal veya sıkıyinetim sırasında çıkarılan KHK'ler Anayasa'ya (m. 148) ve 2949 sayılı Anayasa Mahkımesinin Kuruluşu ve Yargılama Usulleri Hakkında

"Kanun hưkmunde karamame, yuturluk süresi belirtilmişse bu surenin bitiminde, daha once başka bir kanun hakmuncie karamame ile kaldınlmamı̧sa, olağanustu halin sona ermesiyle kendiliģinden yüürlülten kalkar.

"Bu süre içinde yürülukteki mevzuatun kanun hümünde kararnameye aykın hükümleri uygulanmaz" şeklinde dazenlemesine ilişkin onerisi kabul edilmişti. D.M.T.D.; c. 20, s. 793 ve c. 21 , s. 28 . Ancak, madde Milli Gúvenlik Konseyi'nde dę̆iş̧iklikten ónceki haliyle benimsenerek yururluğe konulmuşur.

47 Tasarının D.M. Genel Kurulunda göruşulmesi sırasında KHK ile ilgili genel duzenleme dışında tekrar Bakanlar Kurulunun KHK çıkaracağından söz etmenin yanıltıcı olabileceğ gerekçesiyle maddeden çıkanılması önerilmiştir. Bkz. T. Tan'in değişiklik önerisi DMTD; c. 20 . s. 795 . 
Kanuna (m. 19) göre Anayasa Mahkemesinin denetimi dışındadır. Ancak bu KHK'lerin TBMM'nce görüşülüp yasaya dónüş̧mesi durumunda bu yasalann Anayasa Mahkemeince denetlenebileceğ $i$, zira denetim yasağının onaylanmasından onceki asama için geçerli olduğu kabul edilmektedir ${ }^{48}$.

Ancak, olaganüstü hal KHK'lerinin uluslararası yargı organlan onüne gơturulme olanağı da bir denetim yolu olarak ongorrülmektedir. Türkiye'nin Avrupa Insan Hakları Komisyonuna kişisel başvuru hakkını tanıyan Bakanlar Kurulu karanndaki "ozzel hallerde sơzleşmeden kaynaklanan yükümlülüklerin kısıtlanmasını gerektirecek durum ve gartlar, Türkiye Anayasası'nın 119 ila 122. maddeleri 1 şığında yorumlanmalıdı" cekincesinin başvuru hakkını üç yıl için yenileyen 21.5.1992 tarih ve 92/2982 sayılı kararda kaldınılmıs olması da bu yolun kullanilabileceği yơnünde engelin kalkması olarak gorrulmektedir 49 .

1. Yargı denetimi dışında tutulan oláganüstü hal KHK'si olduğuna gơre, oncelikle KHK'nin bu nitelił̧inin belirlenmesi gerekecektir. Anayasa Mahkemesine gore, Anayasa'ya aykırilık denetimi dışında tutulan KHK'er, "yalnızca olaģnüstü hal süresince olaģanüstü hal ilan edilen yerlerde uygulanmak üzere ve olağanüstä halin gerekli kaldığ konularda çıkanlan KHK'lerdir. Dolayısıyla, bu niteliz̧i taşımayan kurallar" olaz̧anușu hal KHK kuralı niteliğinde sayılamıyacă̌ı̆ından, Anayasa'ya uygunluk denetimine tabi tutulacakur. Bu nedenle Anayasa Mahkemesi onüne getirilen işlemin hukuksal nitelemesini yapmak ve "olağanüstï hal KHK'si" niteliğinde olup olmadığıni incelemek ve bu nitelikte görmediği düzenlemeleri Anayasa'ya uygunluk açısından denetlemek zonunda olduğunu belirtmektedir 50 . Nitekim, Yüksek Mahkeme 424 sayıl KHK'nin 1,2 ve 3. maddelerini olağganüstü hal KHK'si kuralı nitelið̌inde gőrmeyip denetlemiş ve iptal etmiştir 51 . Aynı şekilde 430 sayılı KHK'nin $1 / \mathrm{m}, 5$. ve 6. maddelerinin bazı hüküuleri ile 9. maddesini de bu nitelikte görmeyip iptal etmiştir 52 .

O halde, Anayasa Mahkemesine göre, bir KHK'nin olağanústa hal KHK'si sayılabilmesi için taşıması gereken ozellikler nelerdir?

KHK'nin konusu açısından:

Olağanüstü hal KHK'leri Olağanüstü Hal Kanunu ile saptanan sistem içerisinde "olağanüstü halin gerekli kıldı̌̆ı konularda" uygulamaya yönelik olarak çıkartulabilir. "Bir tür KHK'lerle yalnızca olağanüstü hal ilanını gerektiren nedenler gözetilerek bu nedenlerin ortadan kaldırılması için o duruma ozgü kimi ónlemler alınabilir".

${ }^{48}$ E. Ozbudun, Turk Anayasa Hukuku, Ankara, 1986, s. 208 vd. Turhan loc. cit., s. 18; Anayasa Mahkemesinin, 10.1.1991, E. 990/25-K.991/1 RG; 5.3.1992, say1: 21162, s. 35: 3.7.1991, E,991/6-K.991/10, RG; 8.3.1992, say1: 21115 , s. 18. kararlar1.

49 Aliefendioğlu, loc. cit., s. 41.

$50991 / 10$ sayıl karar RG; 8.3.1992, s. 24-25; $991 / 1$ sayılı karar RG; 5.3 .1992 . 40.

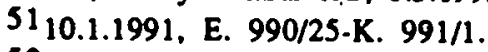

523.7.1991. E. $991 / 6-$ K. $991 / 20$. 
"Olağanüstü halin gerekli kıldığı konular, olağanüstü halin neden ve amaç ogfeleriyle sınurlıdur." 53 .

KHK'nin uygulanacağı yer ạ̧ısından:

Anayasa Mahkemesine göre, "KHK ile getirilen ónlemlerin sadece olałganïstil hal ilan edilen bölge için geçerli olması bölge dışına taşırılmaması gerekir. Ülkenin bu bolgesi için ilan edilen olağanuistü hal nedeniyle olağanüstü hal ilan edilmeyen yerlerde olağanüstü hal KHK'lerine geçerlik tanınamaz" ${ }^{\text {"54 }}$. Nitekim bazı KHK'lerde Olağanüstii Hal Bölgesi sınırları içinde uygulanıcă̆ı aynca belirtilmek yoluna gidilmiştir. (Ömeł̧in KHK/483, m. 2).

KHK'nin uygulanacağı zaman açısından:

Olağanüstü Hal Kanunu ile Sıkıyönetim Kanunu olağanüstü hal ve sıkıyonetim ilan edildiği bölgede olağanüstü hal ve sıkıyönetimin devamı süresince uygulanır. "Olağanüstü halin sona ermesine karşın, olağanüstü hal KHK'sindeki kuralların uygulanmasının devam etmesi olinnaksızdır. Bu nedenle, olağanüstü hal KHK'leri ile yasalarda de ģişiklik yapılamaz." 55 .

Dolayısıyla, Anayasa Mahkemesi KHK kuralının, yukanda belirtilen blçütler açısından, olağanüstü hal KHK kuralı niteliği taşıdığı sonucuna varırsa buna karşı biçim ve öz yönünden dava açılamıyaıcă̆ı için yetkisizlik nedeniyle reddetmek yoluna gitmektedir.

Aksi sonuca vardı̆̆ı takdirde ise, olağanüstü hal KHK'si olarak nitelendirilemiyeceği gerekçesiyl: olağan KHK'lerin denetiminde uyguladı̆̆ı yontemi izleyip biçim ve $6 z$ bakımından A.nayasa'ya uygunluğunu araşurmaktadır. Ömeğin $\mathbf{4 3 0}$ sayılı KHK'nin 1/a maddesini tu nitelikte gören Anayasa Mahkemesi, kural yetki yasasına dayanmadığı; Anayasa'nın "kişi hakları ve ödevleri" bơlümündeki konulanı düzenlediği için Anayasa'nın 91. maddesine; ayrıca temel hak ve ozgürlüklerin sınırlandırılması ancak yasa ile olıcă̆ı ve KHK'lerle düzenlenemiyeceği için 7. maddesi ile olağanüstü hal ilan edilmey'en yerlerde olağanüstü hal KHK'leri uygulanarak Cumhuriyetin nitelikleri arasınd $ı$ insan haklarına saygılı devlet ilkesine de aykırılık oluşturarak Anayasa'nın 2. maddısine aykını bulup iptal yoluna gitmiştir. Kısacası, bu tür KHK'lerin olağanüstü hal KHK'si niteliği taşımayan hiikümleri sonuçta Anayasa'nın 2., 6., 7., 120. ve 121. maddelerine aykın bulunup iptal edilmelidir.

\section{SONUÇ}

Gơrüldügü gibi KHK müessesesi hukukumuza girdigi 1971 yılından bu yana gederek yaygın bir uygulama kaianmıştur. Buna koşut olarak yasama tekniģini gơzardı eden düzenlemelerin de çeşitlenınesi mevzuau izlenmesi zor bir dağınıklığın da içine sokmuştur. KHK uygulamasınd:tki yaygınlığı yasa yapmada karşılaşılan sıkıntılarla

5310.1.1991, E. $990 / 25$ - K. 99i/1, RG; 5.3.1992, sayı: 21162 , s. 39 vd. 3.7.1991, E. $991 / 6-$ K. $991 / 20$, RG; 8.3.1992, sayı: 21165 , s. 22 vd.

54 RG; 8.3.1992, sayı: 21165 , s. 2.3 vd.; RG; 5.3 .1992 , sayı: 21162 , s. 40 vd.

55 RG; 8.3.1992, sayı: 21165 , s 24; RG; 5.3.1992, sayı: 21162 , s. 41. 
açıklamak da olanaksızdır. Zira, bu uygulamanın sık görüldügüu dơnemlerde hükumet TBMM'nde yeterli çoğunluk ve desteğe sahiptir.

Yasama organı bakanlar kuruluna yetki vermekte fazlasıyla cơmert davrandıł̆ gibi, kendisine sunulan KHK'leri görüşme konusunda nedense, Anayasa'nın emri olmasına karşın, oncelik ve ivedilikle görusşme zorunluğunu dikkate almayan tutumunu sürdürmektedir. Dolayısıyla, bugün KHK uygulamasında karşılaşılan sorunlarda ylirutme kadar yasama da pay sahibidir. Yasama organının yetkilerine sahip çıkmasının bu sorunlan büyük olçülde ortadan kaldıracağını düşünmekteyiz. 